\title{
EVOLUTION OF REGIONAL DISPARITIES IN POLAND
}

\author{
Teresa Czyż, Jan Hauke \\ Adam Mickiewicz University, Institute of Socio-Economic Geography and Spatial Management, Poznań, \\ Poland
}

Manuscript received December 8, 2010

Revised version January 11, 2011

\begin{abstract}
CzYŻ T., Hauke J., Evolution of regional disparities in Poland. Quaestiones Geographicae 30(2), Bogucki Wydawnictwo Naukowe, Poznań 2011, pp. 35-48, 5 figs, 5 tables. DOI 10.2478/v10117-011-0016-y, ISBN 978-83-62662-62-3, ISSN 0137-477X.

АвSTRACT. The article presents the state of and changes in the pattern of regional disparities in Poland over the years 1995-2007. The differences in the level of economic development of regions are examined in a dynamic approach on the basis of per capita income, indices of local government finances, and investment outlays. The effect of development-activating factors on regional income is considered. An answer is sought to the question of whether the growth dynamics had a favourable effect on the evolution of regional disparities in Poland.
\end{abstract}

KEY WORDS: regional disparities, regional income dynamics, analysis of convergence, influence of local government finances, development-activating factors, Polish regions

Teresa Czyż, Jan Hauke, Institute of Socio-Economic Geography and Spatial Management, Adam Mickiewicz University, ul. Dzięgielowa 27, 61-680 Poznań, Poland; e-mail: tczyz@amu.edu.pl, jhauke@amu.edu.pl

\section{Introduction}

The chief present-day problem of socio-economic development, in geographical-economic terms, is growing spatial inequality when viewed in a regional approach. In the recent years regional disparities have become of great interest to geographical and economic sciences, as manifested by a fast-growing number of publications on the subject. Worth special notice are empirical-methodological studies of regional differences in the European Union and its member states, e.g. Dunford \& Smith (2000), Petrakos (2001), Maurseth (2001), Domański (2005), Henley (2005), Kosfeld et al. (2006), Kopczewska (2008), Calamai (2009), Smętkowski \& Wójcik (2009), or Rodriguez-Lopez et al. (2009). Those studies focus on regional convergence and in their analysis of change economic aspects come to the fore.
A basis for a study of regional differences is the determination of the state of the economies of regions, primarily in terms of the level of their development, a division of the regions into strong and weak, and the application of a dynamic approach to an examination of changes in those differences. It is assumed that disparities in the level of development of regions (poorly developed regions, polarisation, peripherality) are not favourable, and perhaps even harmful, to the socio-economic development of an entire country. They produce sharp contrasts in the population's standards of living that lead to social tension and conflicts and in the ability of regions to take their own growth-enhancing measures, and limit the possibility of establishing inter-regional cooperation. Efforts to diminish regional disparities have become one of the principal tasks of regional policy. 
Regional differences in development are especially well marked in Poland. Here regional extremes occur at a scale comparable with many European Union states, but at a much lower level of socio-economic development (Czyż 2001, Domański et al. 2003). They are especially readily visible between the western and the eastern part of the country, and between its metropolitan and rural areas.

Regional differences in the level of development in Poland are a heritage of the past: the period of partitions (in the 19th c.) and the postSecond World War period of communist rule with its centralism and location policy typical of a command economy. After the political-systemic breakthrough of 1989 and the transition to a market economy, in the initial stage of the transformation (i.e. in the first half of the 1990s), the old regional disparities were petrified while tendencies towards development polarisation intensified, first because of the recession and difficulties with the adaptation to the new economic system, and then for lack of an active national regional policy (Czyż 1998). It was only in the advanced stage of the transformation in the late 1990s, and especially after 2004 when the economy started to be modernised in the changed conditions connected with European integration, that a new model of regional policy started to be built and implemented in Poland.

"Intra-regional policy should be implemented by regions empowered in terms of competence and finances. This means the creation of legal-institutional conditions of the state's operation that would make regions responsible for designing development-promoting measures and fully able to finance their implementation. Inter-regional policy embraces measures that the state takes towards regions. It involves decisions concerning the redistribution of the state budgetary means earmarked for regional development and intended to ensure the implementation of national priorities, which usually include a reduction of regional disparities in the level of development" (Churski 2008: 35). The Polish model of regional policy, adjusted to the regional strategy of the European Union, has been enriched with presentday factors of regional development, in particular those of fundamental significance for the endogenous development of regions. The state's inter- regional policy includes its intervention carried out as part of the Community's regional policy.

The aim of this article is to analyse the state of and changes in the regional disparities in Poland over the years 1995-2007. The research procedure sought to answer the following cognitive questions:

- Is there a tendency for regional differences in the country to narrow in the course of its dynamic economic development?

- What is the role played by the redistribution of public financial means in regional disparities and their pattern of change? and

- How do factors of development activation affect regional income?

\section{Regional data and methods of analysis}

In the analysis of disparities in the regional system of Poland, the measures of economic development employed were those of per capita regional income (per capita GDP) and per capita regional income expressed as percent of the national average ${ }^{1}$. The regional system is the territorial division of the country into 16 voivodeships. It is assumed that the voivodeship is not only an administrative unit; it is also a territorial subsystem of the state, regional in nature, which integrates and organises the social, economic and cultural activity of its inhabitants in territorial terms.

The analysis of regional differences in Poland covers the years 1995-2007, or the second stage of the systemic transformation and the beginning of modernisation changes. It is assumed that the year 1995, in which the annual increase in the GDP index attained the highest value, at $7 \%$, became a turning point in the transformation in Poland (Table 1). The period 1995-2007 is one of ever-improving macroeconomic stabilisation and fast economic growth, decentralisation of public finances as part of the reform of the territorial organisation of the country (1998), and from 2004,

\footnotetext{
The ratio of regional per capita GDP to national per capita GDP makes it possible to compare those data in a dynamic approach (on the basis of a time series) without resorting to the GDP deflator (Wójcik 2008: 47).
} 
Table 1. GDP dynamics in Poland in the years 1990-2007 (constant prices).

\begin{tabular}{|c|c|c|c|}
\hline Year & $\begin{array}{c}\text { Index value } \\
\text { of GDP } \\
\text { dynamics } \\
\text { (previous } \\
\text { year= 100) }\end{array}$ & Year & $\begin{array}{c}\text { Index value } \\
\text { of GDP } \\
\text { dynamics } \\
\text { (previous } \\
\text { year = 100) }\end{array}$ \\
\hline 1990 & 92.0 & 1999 & 104.1 \\
\hline 1991 & 93.0 & 2000 & 104.0 \\
\hline 1992 & 102.6 & 2001 & 101.0 \\
\hline 1993 & 103.6 & 2002 & 101.4 \\
\hline 1994 & 105.2 & 2003 & 103.8 \\
\hline 1995 & 107.0 & 2004 & 105.3 \\
\hline 1996 & 106.0 & 2005 & 103.6 \\
\hline 1997 & 106.8 & 2006 & 106.2 \\
\hline 1998 & 104.8 & 2007 & 106.7 \\
\hline
\end{tabular}

Source: Central Statistical Office.

the start of modernisation changes connected with Poland's accession to the EU.

The evolution of regional disparities in Poland is studied using convergence methods. In a broad sense, regional convergence means a tendency of the level of regional per capita income to equalise over time (after Johnston et al. 2003: 114). In a narrower sense, convergence is a relatively faster development of economically weak regions than that of strong ones, leading to a reduction of differences between them. An opposite phenomenon is termed divergence.

There is a rich literature on how to formulate mathematical models of the convergence process, including models of spatial econometrics. Their surveys can be found, e.g., in Barro \& Sala-iMartin (1991), Malaga \& Kliber (2007), Ratajczak (2008a), Wójcik (2008), and Kossowski (2009).

In the present article use is made of the classic methods of convergence analysis: $\sigma$-convergence and $\beta$-convergence (Barro \& Sala-i-Martin 1991, 1992; Barro 1994). $\sigma$-convergence is measured as the variance of regional per capita income given by the formula:

$$
\sigma_{t}^{2}=\frac{1}{n} \sum_{i=1}^{\mathrm{n}}\left(y_{i t}-\bar{y}_{t}\right)^{2}
$$

where:

$y_{i t}$ - per capita income in region $i$ in the year $t$,

$n$ - number of regions, and

$\bar{y}_{t}$ - mean regional income in the year $t$.
There is o-convergence in the regional system when the time sequence of the $\sigma_{t}^{2}$ values is decreasing.

In o-convergence, the approach applied to an analysis of changes relies on models of comparative statics, i.e. a comparison is made of how the pattern of regional differences changes with time.

$\beta$-convergence is interpreted as a process of narrowing of inter-regional differences in which regions lagging behind in development display a faster growth rate than advanced ones. $\beta$-convergence is determined on the basis of the formula:

$$
\begin{gathered}
g=\alpha+\beta \log \left(y_{i t}-T\right)+\varepsilon \\
g=\frac{1}{T} \log \left(\frac{y_{i t}}{y_{i t-T}}\right)
\end{gathered}
$$

where:

$g$ - mean annual increase in per capita GDP,

$y_{i t}$ - per capita GDP in region $i$ in the year $t$,

$T$ - number of years from the initial to the final one, and

$\varepsilon$ - random error.

$\beta$-convergence occurs when, in a regression equation of the mean annual increase in regional per capita GDP from its initial level, the coefficient of regression $\beta$ is statistically significant and negative.

As a conception of studying changes in regional disparities, $\beta$-convergence assumes a diachronic approach involving a time series of regional differences; it seeks to determine how this process of change occurs.

\section{Analysis of disparities in regional income in Poland over the years 1995-2007}

In the present analysis of regional differences in the level of economic development in Poland, the chief focus is on their evolution over the years 1995-2007. Still, this cannot be done in abstraction from the state of the regional system in 1995, the reference year for the changes studied. It was a year of sharp contrasts in economic development among the regions. On the scale of per capita GDP defined in proportion to the national 
Table 2. Classification of regions by per capita GDP (Poland $=100 \%$ ).

\begin{tabular}{|c|c|c|c|c|}
\hline \multirow{2}{*}{ Class } & \multicolumn{2}{|c|}{$\begin{array}{c}\text { (a) } \\
1995\end{array}$} & \multicolumn{2}{|c|}{$\begin{array}{c}(\mathrm{b}) \\
2007\end{array}$} \\
\hline & $\begin{array}{l}\text { Index value } \\
\text { (in \%) }\end{array}$ & Region & $\begin{array}{l}\text { Index value } \\
\text { (in \%) }\end{array}$ & Region \\
\hline I & 127.9 & Mazovia & 159.8 & Mazovia \\
\hline \multirow[t]{5}{*}{ II } & 119.0 & Silesia & 108.8 & Lower Silesia \\
\hline & 105.1 & Lower Silesia & 106.3 & Silesia \\
\hline & 103.0 & West Pomerania & 104.4 & Wielkopolska \\
\hline & 101.5 & Pomerania & & \\
\hline & 99.8 & Kujavia-Pomerania & & \\
\hline \multirow[t]{6}{*}{ III } & 98.3 & Wielkopolska & 98.3 & Pomerania \\
\hline & 98.0 & Lubuska Land & 92.1 & Łódź \\
\hline & 98.0 & Opole & 89.8 & West Pomerania \\
\hline & 91.2 & Łódź & 88.6 & Lubuska Land \\
\hline & 87.5 & Małopolska & 86.8 & Kujavia-Pomerania \\
\hline & & & 85.6 & Małopolska \\
\hline \multirow[t]{6}{*}{ IV } & 80.1 & Warmia-Mazuria & 83.1 & Opole \\
\hline & 78.6 & Świętokrzyska Land & 77.0 & Świętokrzyska Land \\
\hline & 78.3 & Lublin & 74.4 & Warmia-Mazuria \\
\hline & 77.2 & Podlasie & 74.3 & Podlasie \\
\hline & 76.3 & Subcarpathia & 67.8 & Lublin \\
\hline & & & 67.8 & Subcarpathia \\
\hline
\end{tabular}

Source: Central Statistical Office.

average, they can be divided into four classes: of a very high, high, average, and low level of economic development (Table 2a, Fig. 1a). Regional income varied in the interval between $128 \%$ and $76 \%$.

a)

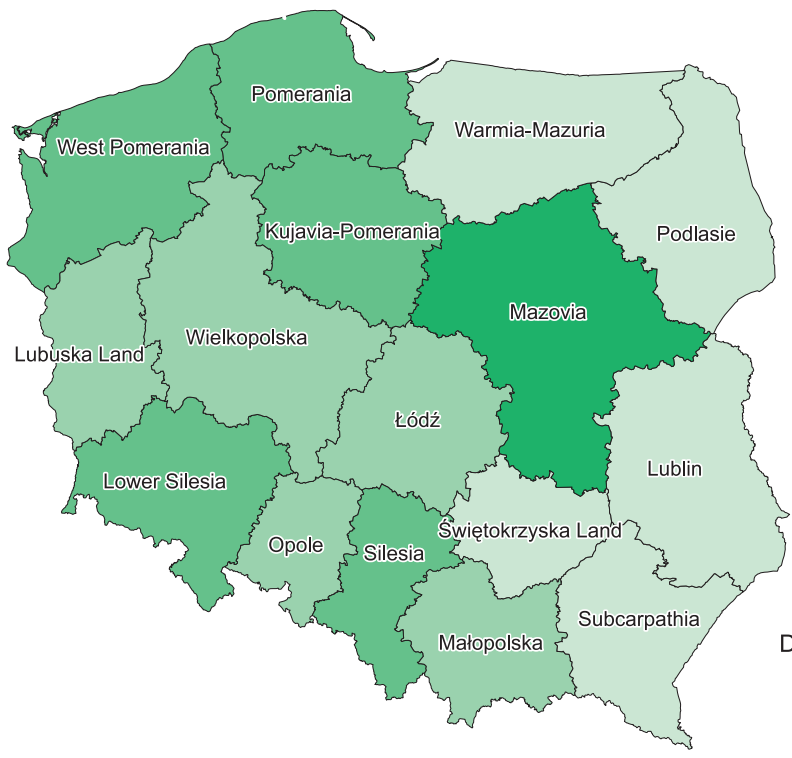

Devero

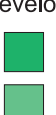

very very high

high

average

low

Over the years 1995-2007, a period of Poland's dynamic economic development, all the regions recorded a marked increase in per capita GDP. Hence, there arises the question of whether economic development was accompanied by any

b)

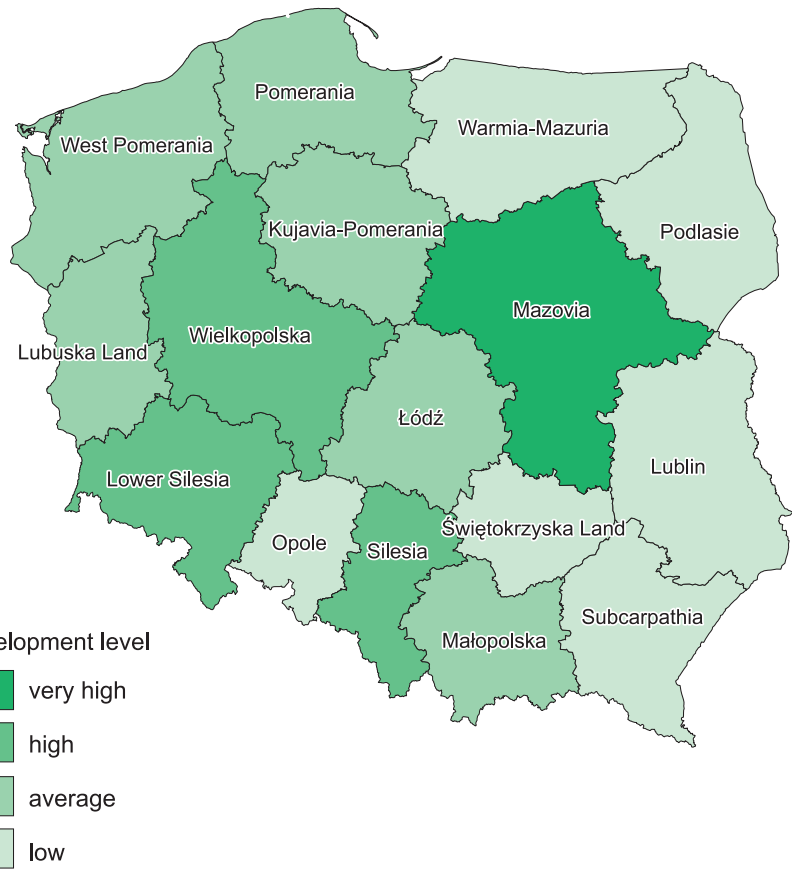

Fig. 1. Regional disparities in Poland: (a) 1995, (b) 2007 
significant changes in regional disparities. To determine the tendency of change in this respect, use is made of methods of convergence analysis.

In the analysis of $\sigma$-convergence, regional differences in the successive years of the period 1995-2007 are measured by the variance of per capita income (defined in proportion to the national average). The variance figures form an increasing sequence, with some fluctuations, and display an upward tendency in regional disparities. The curve of variance describes the evolution of regional differences between 1995 and 2007 (Fig. 2). On the basis of its shape, one can discern fluctuations and their corresponding subperiods in the pattern of change in regional disparities: a steep increase in disparities in the years 1995-2001, their slight decrease in 20022004, and another slow increase in 2005-2007. It is worth noting that the curve of variance of per capita income plotted for 15 regions without Mazovia (and its metropolitan area of Warsaw) shows a smaller increase in regional disparities.

In the analysis of $\beta$-convergence, a study is made of the dependence between the dynam- ics of change in per capita GDP figures over the years 1995-2007 and this index at the start of the period, i.e. in 1995. This is intended to answer the question of whether regions lagging behind in development (occupying a low position on the scale of the 1995 value of per capita GDP) display a tendency towards a faster increase in this income than economically advanced ones (occupying a relatively high initial position on the income scale). The estimation of the model of $\beta$-convergence leads to an equation of the form:

$$
\begin{gathered}
y=0.0204 x-0.0968 \\
R^{2}=0.147, \text { significant at } \alpha=0.1427
\end{gathered}
$$

where:

$y$ - log of the mean annual increase in regional per capita GDP, and

$x$ - log of regional per capita GDP in 1995.

The goodness of fit of the model is poor. The regression coefficient $\beta=0.0204$ is low and positive, which shows an absence of $\beta$-convergence. The diagram of the regression equation is an upward curve, which even means the opposite, or

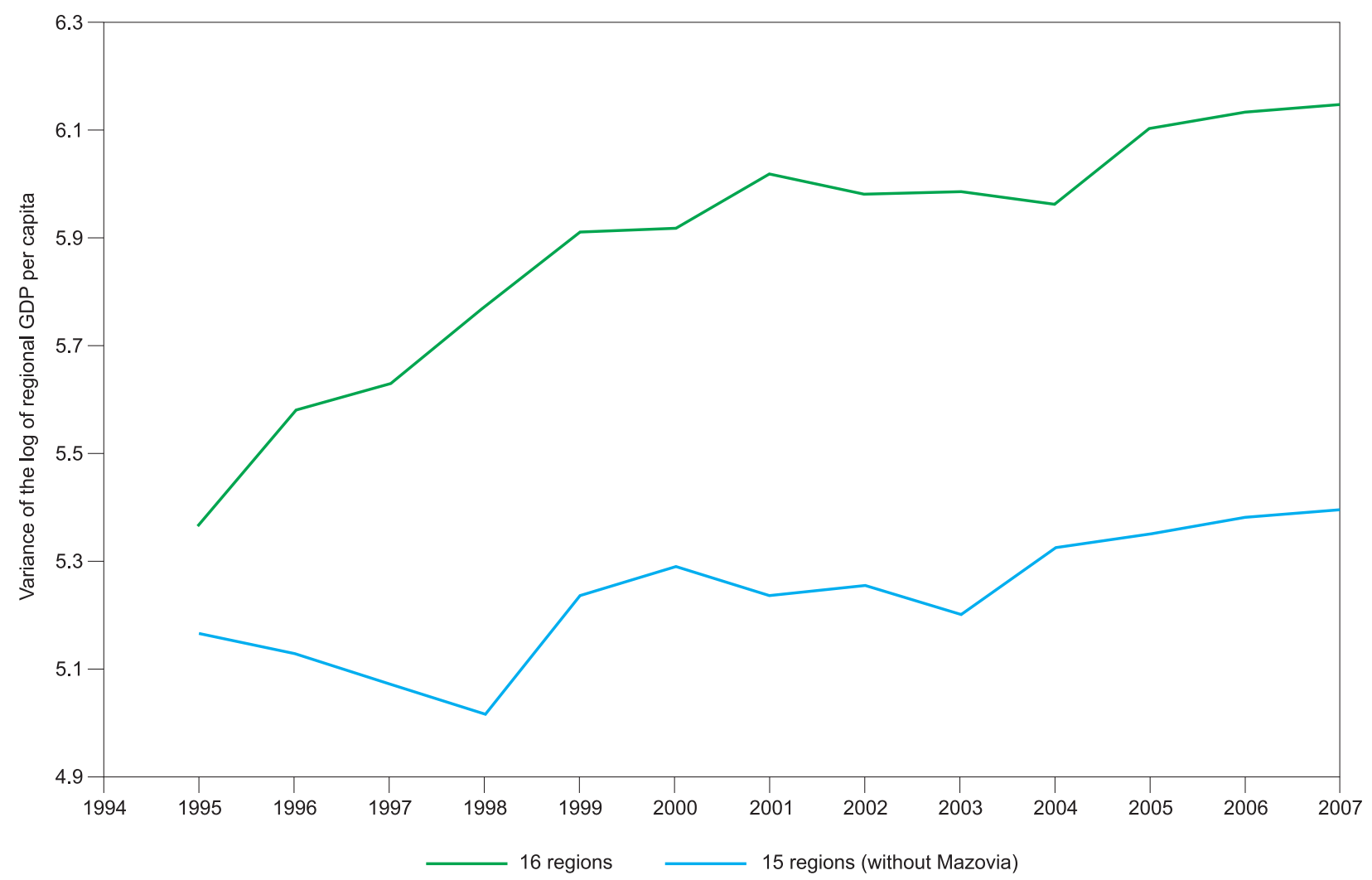

Fig. 2. Sigma convergence (1995-2007) 
divergence, i.e. a weaker growth rate of per capita income in regions of low income than in those with a relatively high initial income (Fig. 3).

Thus, in the years 1995-2007 there was no 'catching up' of the Polish regions on the scale of per capita GDP. However, it is worth noting that for the subperiod 2000-2007 the $\beta$-convergence equation assumes the form:

$$
\begin{gathered}
y=0.0109 x-0.0519 \\
R^{2}=0.133, \text { significant at } \alpha=0.1639
\end{gathered}
$$

The regression coefficient $\beta=0.0109$ indicates that in the subperiod 2000-2007 the divergence was weaker than in the entire period 1995-2007.

The results obtained using the $\sigma$ - and $\beta$-convergence methods are found to indicate a steady increase in regional differences, with only slight changes in its rate. In 2007 regional disparities in regional income ranged from a maximum of $159.8 \%$ in Mazovia to a minimum of $67.8 \%$ in Subcarpathia, up from the 1995 span of $128 \%-$ $76 \%$. Still, the high coefficient of correlation $(r=$ 0.885 ) between the distributions of the regions on the scale of per capita GDP in 1995 and 2007 is in- dicative of a good fit between those distributions in the two years (Tables 2a, b, Figs 1a, b).

Regional differences in Poland show a clear tendency towards petrifaction in the course of economic development. There is a growing polarisation of development in the regional system. In 2007 Mazovia fixes its highest position on the scale of per capita GDP: its income exceeds the national average by $60 \%$ (in 1995 by $28 \%$ ), which deepens the differences in the country's regional system. The increase in the level of development of Mazovia, and more precisely of the Warsaw metropolitan area, confirms, on the one hand, the global tendency of growth in the importance of metropolitan regions in development processes, and on the other, the persistence of a centralisation tendency in the Polish economy. The composition of the class of regions at a high level of development has long been fixed: it includes Lower Silesia, Silesia and Wielkopolska, all with large urban agglomerations. Missing from the class are the regions of Łódź and Pomerania, also with urban agglomerations but at a stage of economic restructuring, and Małopolska with persistent internal development contrasts between the urban agglomeration of Cra-

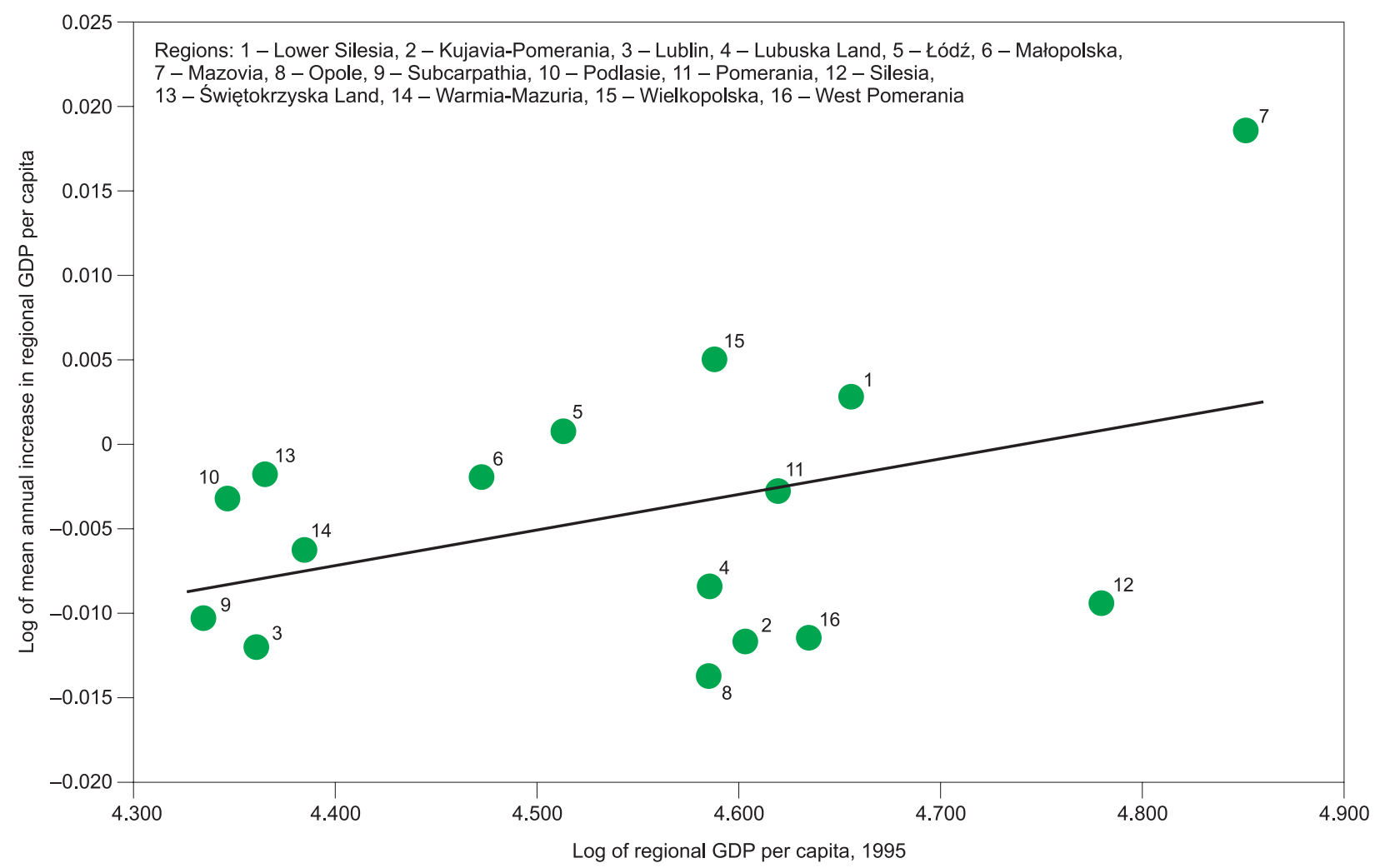

Fig. 3. Beta convergence (1995-2007) 
cow and its regional hinterland. A decline in the position of the western regions of Opole, West Pomerania and Lubuska Land proves a near-border location to have a poor effect on accelerating the rate of regional development. The composition of the class of regions at a low level of development is constant, although it expanded in 2007 to include Opole. The other regions are generally those of eastern Poland, poorly urbanised, dominated by traditional agriculture, and lagging behind in development, whose economies have not changed significantly in the transformation period. While being targets of the Community's special financial assistance in the pre-accession period and after Poland had joined the EU, owing to too short a time perspective their economies still fail to show the structural changes that are a condition of further development.

\section{Role of local government finances in the formation of regional differences}

The finances of the regions are examined in terms of the incomes of the local governments. Those are a total of financial means at the disposal of the three levels of territorial self-government (commune, poviat, and voivodeship) that are independent of one another and the central authorities, and that engage in financial management in support of various measures for the development of their respective regions. The temporal range of the analysis covers the years 2000-2007, i.e. the period after the establishment in 1998 of new voivodeships as part of a reform of the country's territorial organisation that sought to implement, among other things, the principles of fiscal decentralisation. Local government income is the budgetary revenues of territorial self-government units; it includes their own income, targeted subsidies, a general-purpose subsidy from the state budget, and the co-funding from the European Union². Lo-

\footnotetext{
The official materials published by the Central Statistical Office (GUS) do not contain information about the proportion of the Community money in local government finances in the years 2000-2007, i.e. in the period before and after Poland's accession to the EU. On the basis of the 2007 data on the Community funds, it is estimated that they accounted for an average $4 \%$ of the regions' budgetary means, with the extremes of $6.6 \%$ in Lubuska Land and 2\% in Mazovia.
}

cal government finances crucially depend on the income generated in a region.

In the analysis of the effect of the regions' local government finances on stimulating their development and on the pattern of inter-regional differences in the years 2000-2007, the point of departure is a description of the state of the finances in 2000. At that time the regional per capita income figures ranged from $120 \%$ to $89 \%$ of the national average. There were four classes of regions by this criterion (Table 3a). The range of the regional variation in the index of local government finances was much smaller than that of per capita GDP $(150 \%$; 69\%), which proves local government finances to have been more equalised over the regional system. This is also corroborated by the coefficient of regional variation equal to $8.4 \%$ (as against 19.9\% in the case of per capita GDP).

In 2000 a region's level of local government finances did not always correspond to its level of economic development. The extent of overlap of the classifications of the 16 regions by the index of per capita local finances and by that of per capita GDP is given by the inconsistency metric, which amounts to $2(16-8)=16$ (if the classifications were totally inconsistent, the metric would assume the value 32; Ratajczak 2008b). There are clear discrepancies in the case of Wielkopolska and Silesia, at an average level of local government finances and a high level of development, as well as Warmia-Mazuria and Świętokrzyska Land, at an average level of local government finances and a low level of development. Among regions at an average level of development, Małopolska, Łódź and Kujavia-Pomerania show a low level of local government finances, and Lubuska Land, a high level. Over the years 2000-2007, local government finances per capita display an upward tendency in both the national and regional approaches, despite some instability in the annual pattern. Changes in the index of local government finances are linked with an increase in per capita GDP, which determines the level of local government finances.

The regression model employed to define the effect of per capita GDP (the independent variable $y$ ) on local government finances (the dependent variable $z$ ) has the form:

$$
z=a+b y
$$


Table 3. Classification of regions on the scale of per capita local government finances (Poland $=100 \%$ ).

\begin{tabular}{|c|c|c|c|c|}
\hline \multirow{2}{*}{ Class } & \multicolumn{2}{|c|}{ (a) 2000} & \multicolumn{2}{c|}{ (b) 2007 } \\
\cline { 2 - 5 } & Index value (in \%) & Region & Index value (in \%) & Region \\
\hline I & 119.6 & Mazovia & 128.3 & Mazovia \\
\hline II & 111.1 & Lower Silesia & 107.8 & Power Silesia \\
\hline & 105.8 & West Pomerania & 107.0 & Lubuska Land \\
\hline & 105.4 & Lubuska Land & 100.5 & West Pomerania \\
\hline & 102.6 & Pomerania & 100.5 & Warmia-Mazuria \\
\hline & & & 100.5 & Wielkopolska \\
\hline III & 99.4 & Warmia-Mazuria & 96.3 & \\
\hline & 98.5 & Silesia & & Małopolska \\
\hline & 95.0 & Opole & & Kujavia-Pomerania \\
\hline & 94.8 & Świętokrzyska Land & & Silesia \\
\hline & 94.7 & Wielkopolska & & Opole \\
\hline IV & 93.3 & Kujavia-Pomerania & 93.6 & Subcarpathia \\
\hline & 92.7 & Łódź & 93.6 & Łódź \\
\hline & 92.1 & Subcarpathia & 93.3 & Podlasie \\
\hline & 91.0 & Podlasie & 92.4 & Świętokrzyska Land \\
\hline & 90.7 & Lublin & 90.8 & Lublin \\
\hline & 89.3 & Małopolska & 89.8 & 89.3 \\
\hline
\end{tabular}

Source: Central Statistical Office.

In this equation the coefficient of regression $b$ of the dependent variable $y$ defines the average number of units by which variable $z$ grows when there is a unit increase in $y$. As a result of an estimation of the parameters of the regression model referring to relationships at the scale of the country, the following equation was obtained:

$$
z=0.1379 y-835.04
$$

$$
R^{2}=0.98, \text { significant at } \alpha=0.00000001
$$

It follows from the equation that in the years 2000-2007 there was a close relation at the scale of the country between per capita GDP and local government finances: a unit increase in per capita GDP produced a mean growth by 0.14 unit in local government finances per capita. In the regions, the coefficient of regression $b$ varied between 0.11 and 0.19 . There are no clear regularities in the regional distribution of the coefficient, interpreted as the growth rate of local government finances following an increase in per capita GDP. Still, when comparing regional figures against the national average, one can observe coefficient $b$ to have higher values in three regions at a low level of development (Subcarpathia, Lublin and Podlasie), and lower values in those at a very high (Mazovia) and a high level (Silesia). It is also worth noting that, owing to big interregional differences in regional income, the differences in the values of the regression coefficient $b$ do not cause a significant change in the position of those regions on the scale of local government finances in 2007.

Over the years 2000-2007, regional disparities in the index of local government finances kept changing: they dwindled between 2000 and 2003 to widen again in the period 2004-2007. The latter was largely connected with the instability of the transfer of financial means from the state budget to those of local government units ${ }^{3}$.

Between 2000 and 2007, the national and regional indices of local government finances almost doubled. The variation of the regional indices of local government finances was in the interval $(128 ; 86 \%)$, wider because of the growth in the supremacy of Mazovia on the scale of this index (Table 3b). On eliminating Mazovia, the index varied within the same interval as in 2000 . Between-class shifts of the regions were due to small changes in the value of the index (ex-

3 In 2003 a new Income of Territorial Government Units Act was passed. 
pressed as per cent of the national average). The only region to register a substantial change was Świętokrzyska Land (a fall from $94.8 \%$ in 2000 to $89.2 \%$ in 2007). Still, as a result of the shifts, the class of a low level of local government finances expanded.

Regional differences in the index of local government finances as measured by the coefficient of variation grew from $8.4 \%$ in 2000 to $10.4 \%$ in 2007, while regional differences in per capita GDP increased from $19.9 \%$ to $22.3 \%$. In 2007 , the greatest contrasts between the level of local government finances and that of economic development persisted in Silesia (a low level of local government finances vs. a high level of development) and Warmia-Mazuria (a high level of local government finances vs. a low level of development). There had formed a fixed group of regions at a low level of local government finances and a low level of development embracing Opole, Subcarpathia, Podlasie, Świętokrzyska Land, and Lublin.

Summing up the results of the analysis, it was found that in 2007 there was a clear predominance of regions (10) at a low and an average level of local government finances compared with the national average. Wielkopolska and Silesia showed a mismatch between their local government finances and high level of economic development. Only four regions enjoyed a favourable situation in terms of their level of local government finances: it was high in West Pomerania, Lubuska Land and Pomerania at an average level of development, and in Warmia-Mazuria at a low level of development.

On the basis of this picture of the regional level of local government finances, one can conclude that the pattern of regional differences in this respect, while less pronounced, largely coincides with that of disparities in per capita GDP. The possibilities of using local finances to enhance development and reduce inter-regional differences prove to be very limited. A low level of local government finances in most regions is also a barrier to the absorption of EU means, contingent as they are on a region's own input.

A substantial portion of local government finances of the regions, or their budgetary income, is earmarked for investment. Featuring significantly in the structure of investment outlays are those for physical infrastructure, which crucially determines a region's further economic development. In 2000, the proportion of budgetary income spent on investment amounted to $18 \%$ at the scale of the country, varying in the regional system from $13 \%$ (Warmia-Mazuria) to 24\% (Mazovia). The highest index of per capita investment outlays was recorded in Mazovia (161\% of the national average), and the lowest, in the Lublin region (70\%) (Table 4a). The three other regions with indices of per capita investment outlays higher than the national average were Lower Silesia, Pomerania and Świętokrzyska Land. Regional differences in investment outlays were reflected by a coefficient of variation equal to $23.6 \%$. In 2000 investment outlays showed a connection with local government finances per capita, as can be concluded from the coefficient of correlation $r$ equal to 0.68 . However, there are deviations from this dependence. Significant negative deviations were recorded in the regions of Warmia-Mazuria and Opole, characterised by a low level of investment outlays and an average level of local government finances. Significant positive deviations indicating a higher level of investment outlays than that implied by local government finances occurred in Świętokrzyska Land. Over the years 2000-2007 there was an increase in regional per capita investment outlays, but fluctuations in the annual pattern were wide. The instability of the level of investment outlays in the individual regions can be indicative either of a concentration of those outlays in one year, or of an erratic nature of investment processes (Motek 2006). In 2007 per capita investment outlays almost doubled in the country and the regions. They accounted for $17 \%$ to $22 \%$ of the budgetary income of the regions, with a national average of $20 \%$. The extreme values of the index were found in the same regions as in 2000: Mazovia and Lublin, at $141 \%$ and $72 \%$ of the national average, respectively; this interval was smaller than in 2000 (Table 4b). There was a narrowing of the difference between the first (Mazovia) and the second region (Lower Silesia), and between the second and the last region (Lublin). This produced distinct changes in the position of nine regions on the scale of the index of investment outlays, including Świętokrzyska Land and West Pomerania owing to a significant decline in this index, as well as Opole, Łódź, 
Table 4 . Classification of regions by per capita investment outlays (Poland $=100 \%$ ).

\begin{tabular}{|c|c|c|c|c|}
\hline \multirow{2}{*}{ Class } & \multicolumn{2}{|c|}{ (a) 2000} & \multicolumn{2}{c|}{ (b) 2007 } \\
\cline { 2 - 5 } & Index value (in \%) & Region & Index value (in \%) & Region \\
\hline I & 161.5 & Mazovia & 141.2 & Mazovia \\
\hline II & 122.5 & Lower Silesia & 114.9 & Lower Silesia \\
\hline & 109.6 & Pomerania & 113.8 & Opole \\
\hline & 101.7 & Świętokrzyska Land & 100.9 & Małopolska \\
\hline & & & 100.1 & Silesia \\
\hline III & 99.4 & Lubuska Land & 98.0 & Wielkopolska \\
\hline & 98.9 & West Pomerania & 97.1 & Lubuska Land \\
\hline & 97.5 & Silesia & 90.6 & Łódź \\
\hline & 89.6 & Wielkopolska & 90.4 & West Pomerania \\
\hline & 86.0 & Subcarpathia & 87.8 & Kujavia-Pomerania \\
\hline & 84.2 & Małopolska & 86.6 & Warmia-Mazuria \\
\hline & 82.6 & Podlasie & 85.3 & Subcarpathia \\
\hline & 82.0 & Kujavia-Pomerania & & Podlasie \\
\hline IV & 72.3 & Opole & 78.2 & Świętokrzyska Land \\
\hline & 71.2 & Łódź & 76.9 & Lublin \\
\hline & 70.0 & Warmia-Mazuria & 74.7 & 71.8 \\
\hline
\end{tabular}

Source: Central Statistical Office.

Małopolska and Warmia-Mazuria owing to its significant growth.

In 2007 regional differences in the index of investment outlays narrowed (Table $4 b$ ). The coefficient of regional variation in this index was $17.8 \%$. There appeared a tendency towards a greater dependence of the level of investment outlays on that of local government finances as defined by the coefficient of correlation $r=0.75$. Still, disparities among regions in terms of investment outlays remained greater than in terms of the level of local government finances, which can indicate a steady concentration of regional investment activity conducted by local governments.

\section{Effect of development-activating factors on regional income}

In an analysis of regional differences in Poland, a significant research problem is the identification of the role that development-activating factors play in the shaping of regional income. Development-activating factors are those properties of regions that are active and controllable in nature, and their implementation is a condition for a restructuring and modernisation of the economies of regions and their dynamic development (Chojnicki \& Czyż 2005, 2006). Those fac- tors in the present-day socio-economic transformation of Poland include primarily: human and social capital, R\&D potential, modern sectors of the economy (representing a knowledge-based economy), exports, foreign capital, and the European Union assistance funds.

An analysis of the impact of the developmentactivating factors on the level of economic development of regions as measured by per capita income requires the formulation and justification of answers to the following questions:

(a) Do all hypothetic development factors display a statistically significant relationship with the level of regional income?

(b) Is the strength of this relation different depending on the factor?

(c) Does the occurrence of those factors in the regions lead to a reduction in regional differences?

A statistical analysis of the effect of development-activating factors on the regions involves a procedure that consists of three stages. In the first, six development factors treated as properties of a region are assigned specified socio-economic variables ${ }^{4}$. The set includes the values of 17 variables for 16 regions (voivodeships) valid in the years 2006-2007.

4 Their choice was determined primarily by access to data from official regional statistics. 
Table 5. Correlation of the empirical variables with the first component $\mathrm{V}_{1}$ (statistically significant at the $\alpha=0.001$ level)

\begin{tabular}{|l|l|c|}
\hline \multicolumn{1}{|c|}{ Variables } & $\begin{array}{c}\text { Coefficient } \\
\text { of correla- } \\
\text { tion }\end{array}$ \\
\hline 1. & students per 1,000 population & 0.7521 \\
\hline 2. & $\begin{array}{l}\text { non-governmental organisations per } \\
10,000 \text { population }\end{array}$ & 0.7566 \\
\hline 3. & $\begin{array}{l}\text { employment in R\&D per 1,000 eco- } \\
\text { nomically active population }\end{array}$ & 0.9432 \\
\hline 4. & per capita outlays for R\&D (in zlotys) & 0.8986 \\
\hline 5. & $\begin{array}{l}\text { outlays for R\&D in relation to GDP } \\
\text { (in \%) }\end{array}$ & 0.7670 \\
\hline 6. & $\begin{array}{l}\text { proportion of employment in high-tech } \\
\text { services (HTS) }\end{array}$ & 0.9390 \\
\hline 7. & $\begin{array}{l}\text { foreign capital per 10,000 population } \\
\text { (in million zlotys) }\end{array}$ & 0.8764 \\
\hline 8. & $\begin{array}{l}\text { companies with foreign capital partici- } \\
\text { pation per 10,000 population }\end{array}$ & 0.8246 \\
\hline
\end{tabular}

Source: own calculations.

In the second stage the set of 17 variables is reduced using the principal components meth$\mathrm{od}^{5}$. The one with the greatest share in the total variance (accounting for $55 \%$ of the variance) is chosen as the first component $\mathrm{V}_{1}$. It has a complex internal structure and displays significant correlations with only eight out of the 17 variables describing the development factors (Table 5). Component $V_{1}$ is a meta-variable connected in terms of meaning with four development factors showing regional links: human and social capital, R\&D potential, modern sectors of the economy, and foreign capital (Fig. 4).

In the third stage of the procedure, a dependence estimation is carried out in two regression models. Model I accounts for the relation between component $\mathrm{V}_{1}$, interpreted as a pattern of development factors (the explanatory variable), and regional income. It assumes the form of a simple linear regression equation:

$$
y_{i}=a_{0}+a_{1} v_{1 j}
$$

where:

$y_{i}$ - per capita income in region $j$, and

$v_{1 j}$ - the value of component $\mathrm{V}_{1}$ in region $j$.

5 Use was made of the STATISTICA 8.0 program.

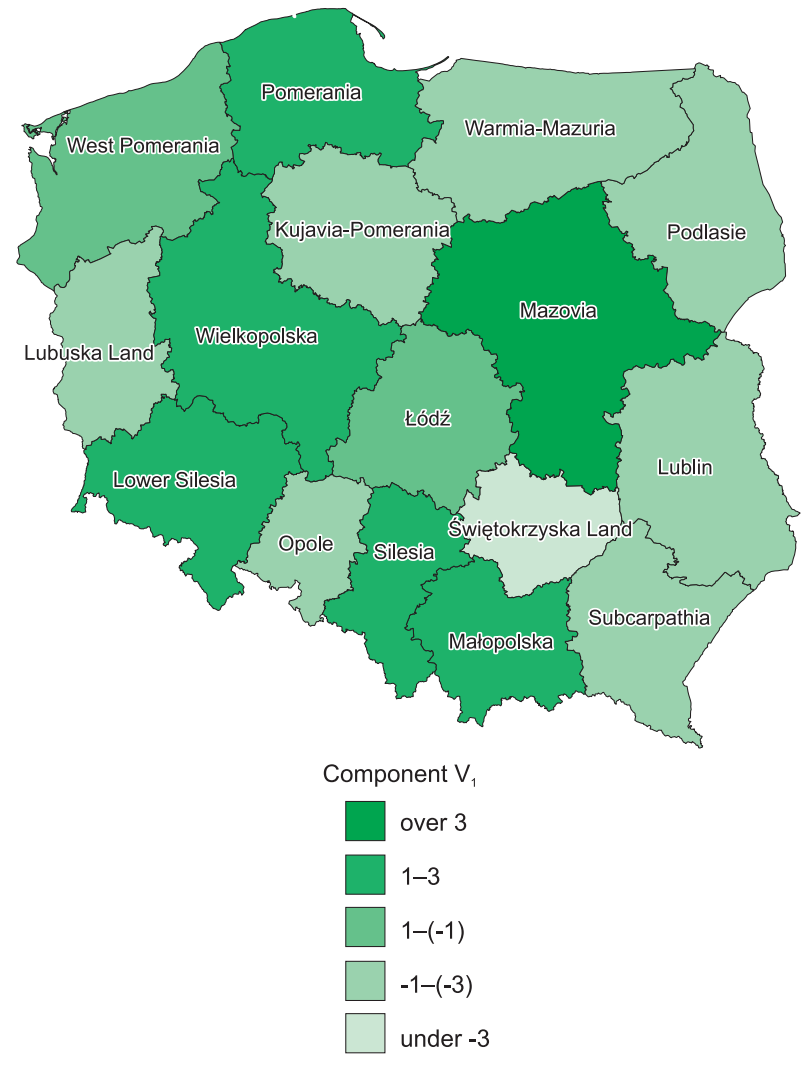

Fig. 4. Regional distribution of the values of the first component $\mathrm{V}_{1}$.

As a result of the estimation of regression coefficients with the least-squares method, the following equation was obtained ${ }^{6}$ :

$$
\begin{gathered}
y_{j}=0.31 v_{1 j} \\
R^{2}=0.89, \text { significant at } \alpha<0.001
\end{gathered}
$$

Model II is a multiple regression one with the eight variables explaining the regional income pattern which 'build' component $\mathrm{V}_{1}$. They are empirical variables describing the configuration of four development factors. The multiple regression model has the form:

$$
y_{j}=b_{0}+b_{1} u_{1 j}+b_{2} u_{2 j} \ldots+b_{8} u_{8 j}
$$

where:

$y_{j}$ - per capita income in region $j$, and

$u_{i j}$ - the value of variable $i(i=1,2,3, \ldots, 8)$ in region $j$.

6 Since standardised variables are used in the model, in the estimated equation the absolute term is equal to zero. 
As a result of the estimation of parameters of the model using the method of forward stepwise regression with standardised variables, the following equation was obtained:

$$
y_{j}=0.52^{* *} u_{7}+0.27^{*} u_{6}+0.22 u_{8^{\prime}} R^{2}=0.91
$$

** - significant at $a<0.001$,

* - significant at $a<0.01$.

The modelling of the dependences leads to the following findings:

(1) A statistically significant relation with regional income is shown by four development-activating factors represented by component $V_{1}$.

(2) Out of the development factors 'contained' in component $\mathrm{V}_{1}$, those that influence regional income most strongly are foreign capital invested in the region and modern sectors of the economy.

(3) Regions which do not show a regional income proportional, even approximately, to factors of development belong to various classes of the level of income. Regional deviations from the dependence $y_{j}=0.31 v_{1 j}$ are defined by re- siduals from regression. Significant negative values of the residuals are recorded in the regions of Małopolska, Pomerania and Lublin, in which the effect of development-activating factors in relation to the magnitude of those factors is poor. Significant positive values of the residuals in Mazovia, Świętokrzyska Land and Lubuska Land indicate a higher level of regional income than follows from its connection with development-activating factors.

The regional deviations can be commented as follows. (a) The effect of the selected development-activating factors varies from region to region. They practically do not contribute to a reduction of inter-regional differences. Most of the factors show a strong spatial concentration, in particular the foreign capital factor (Fig. 5). (b) Only a part of regional income qualifies as an effect of the development factors taken into consideration in the model. The regional distribution of residuals from regression justifies an introduction of further explanatory factors into it, which requires a continuation of the research.

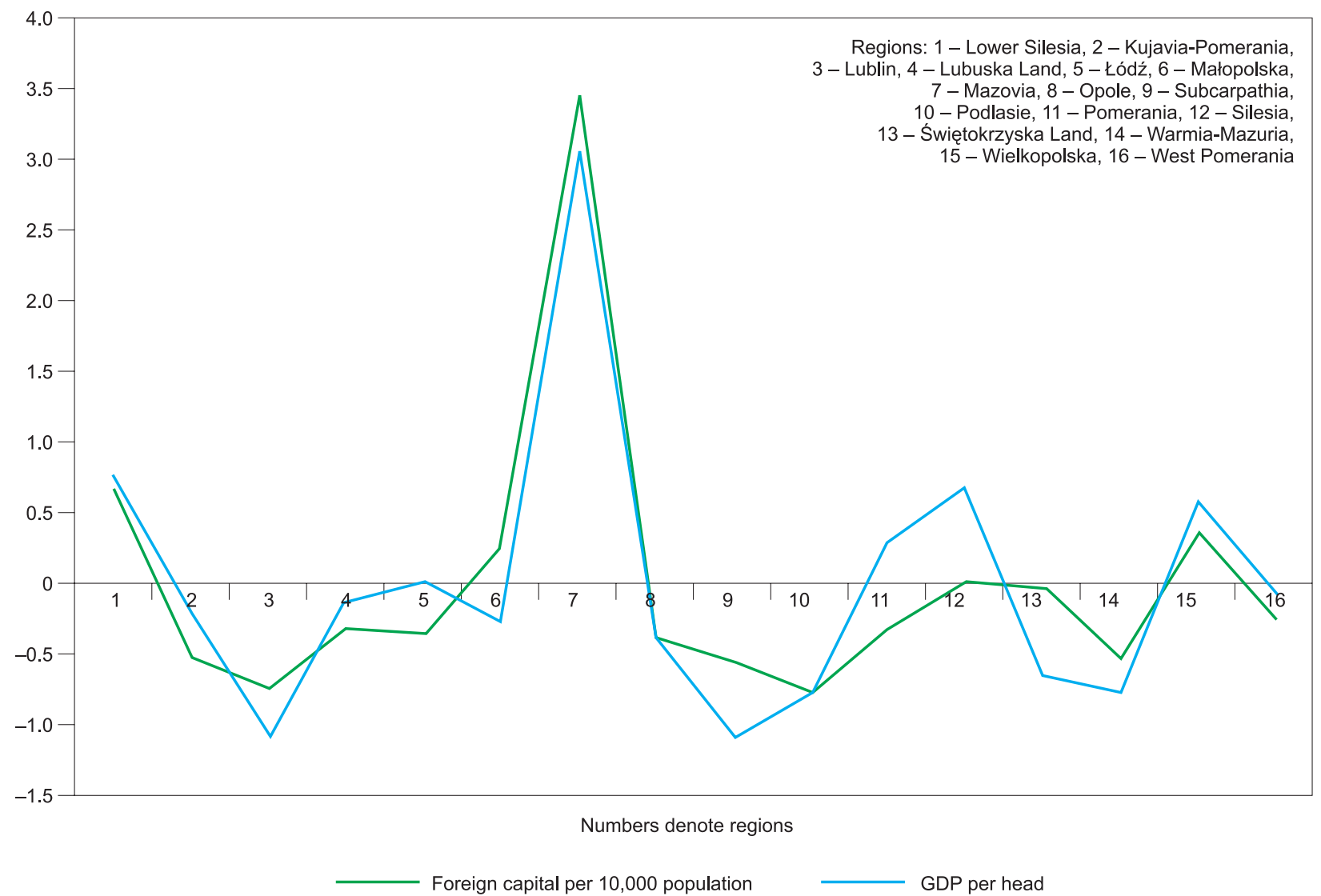

Fig. 5. Regional distribution of income per head and foreign capital per head in 2006. 


\section{Conclusion}

In the years 1995-2007, a period of dynamic growth in Poland, regional contrasts are still strong. The development process does not involve regional convergence. Regional differences in per capita income substantially determine regional differences in the income and investment outlays of local governments. The level of local government finances in the regions, not matching development-oriented tasks, limits the possibilities of the local authorities to stimulate economic development. The influence of the development-activating factors does not contribute significantly to an equalisation of interregional differences.

The research on changes in regional disparities in Poland has shown that the regional policy conducted in Poland so far, oriented towards an equalisation of inter-regional differences as barriers to development, has failed to produce the expected results and should be revised. The change in regional policy, advocated and discussed not only in Poland but also in other EU countries, rests on the polarisation-diffusion model of development and the conception of functional regional cohesion (cf. Gorzelak 2007, Churski 2009). A new regional policy means a departure from the principle of reducing inter-regional differences understood as the principal target of this policy. Rather, it seeks to derive benefits from the given state of disparities among regions through an increase in the intensity of socio-economic links between the regions.

In the discussion of regional policy in Poland, attention is also paid to the necessary differentiation between regional disparities in the level of economic development and in the standards of living (Domański 2010). On the assumption that the advancing spatial concentration of economic activity is justified by specified economic benefits, a major challenge for regional policy is thus a reduction of disparities in the standards of living among regions differing in the intensity of economic activity. A solution of the problem of regions with low standards of living should be sought in their economic and social integration with regions of economic growth. The policy of public authorities should be designed to support this integration through efforts to develop trans- port infrastructure, the institutional milieu, public services, and human capital.

\section{References}

BARRO R.J., 1994. Economic growth and convergence. International Center of Economic Growth. Occasional Papers 46: 1-29.

Barro R.J. \& Sala-I-Martin X., 1991. Convergence across states and regions. Brookings Papers in Economic Activity 1: 107-182.

Barro R.J. \& SALA-I-MARTin X., 1992. Convergence. Journal of Political Economy 100 (2): 223-251.

CAlamai L., 2009. The link between devolution and regional disparities: evidence from Italian regions. Environment and Planning A 41: 1129-1151.

CHојNICKI Z. \& CZYŻ T., 2005. Rozwój społeczno-gospodarczy $\mathrm{w}$ ujęciu regionalnym (Socio-economic development in a regional approach). Biuletyn KPZK PAN 219, Warszawa: 8-23.

Chojnicki Z. \& CZYŻ T., 2006. Aspekty regionalne gospodarki opartej na wiedzy w Polsce (Regional aspects of the knowledge-based economy in Poland). Bogucki Wydawnictwo Naukowe, Poznań.

CHURsкi P., 2008. Czynniki rozwoju regionalnego i polityka regionalna w Polsce w okresie integracji z Unia Europejska (Regional development factors and regional policy in Poland in the period of integration with the European Union). Seria Geografia, 79, Uniwersytet im. Adama Mickiewicza w Poznaniu, Wydawnictwo Naukowe UAM, Poznań.

CHURSKi P., 2009. Polityka regionalna w okresie 2004-2006 a spójność i konkurencyjność Wielkopolski (Regional policy in the period 2004-2006 and the cohesion and competitiveness of Wielkopolska). In: T. Czyż (ed.), Charakter regionalny województwa wielkopolskiego. Biuletyn IGSEiGP UAM, Seria Rozwój Regionalny i Polityka Regionalna, 9, Bogucki Wydawnictwo Naukowe, Poznań: 97-133.

CZYŻ T., 1996. Nierówności regionalne w okresie transformacji społeczno-gospodarczej w Polsce (Regional disparities in Poland in the period of the socio-economic transformation). Acta Universitatis Wratislaviensis, 1814, Studia Geograficzne, LXV, Wrocław: 27-49.

CZYŻ T., 1998. Polaryzacja rozwoju regionalnego w okresie transformacji społeczno-gospodarczej w Polsce (Polarisation of regional development in Poland in the period of the socioeconomic transformation). In: Parysek J. \& Rogacki H. (eds), Przemiany społeczno-gospodarcze Polski lat dziewięćdziesiatych. Bogucki Wydawnictwo Naukowe, Poznań: 47-63.

CzYŻ T., 2001. Zróżnicowanie regionalne Polski w układzie nowych województw (Regional differences in Poland in the new voivodeship system). Biuletyn KPZK PAN 197: 7-35.

DoMAŃSKI B., 2005. The economic performance and standard of living of post-communist European countries since 1989: factors and processes behind. Geographia Polonica 78 (2): 107-126.

DoMAŃSKI B., 2010. Should we fight local and regional disparities in economic development in Poland? Studia Regionalia KPZK PAN 27 (1): 132-141.

DOMAŃSKi B., GUZIK R. \& MiceK G., 2003. Zróżnicowanie regionalne krajów Europy Środkowo-Wschodniej i jego zmia- 
ny w latach 1995-2000 (Regional differences in the states of Central and Eastern Europe and their changes over the years 1995-2000). Biuletyn KPZK PAN 204: 125-142.

DunFord M. \& SMITH A., 2000. Catching up or falling behind? Economic performance and regional trajectories in the “New Europe". Economic Geography 76 (2): 169-195.

GorzelaK G., 2007. Rozwój polskich regionów a polityka spójności Unii Europejskiej (Development of Polish regions and the EU cohesion policy). In: Gorzelak G. (ed.), Polska regionalna i lokalna w świetle badań EUROREG-u. Wydawnictwo Naukowe Scholar, Warszawa: 12-34.

HenLEY A., 2005. On regional growth convergence in Great Britain. Regional Studies 39 (9): 1245-1260.

Johnston R.J., Gregory D., Pratt G. \& Watts M. (eds), 2003. The dictionary of human geography. Blackwell Publishing, London.

KOPCZEWSKA K., 2008. Renta geograficzna a rozwój społeczno-gospodarczy (Geographical rent and socio-economic development). CeDeWu, Warszawa.

Kosfeld R., ECKey H.F. \& Dreger C., 2006. Regional productivity and income convergence in Unified Germany 1992-2000. Regional Studies 40 (7): 755-767.

KossowsKI T., 2009. Konwergencja przestrzenna - aspekty teoretyczne (Spatial convergence: Theoretical aspects). In: Churski P. (ed.), Praktyczne aspekty badań regionalnych - varia vol. II. Biuletyn IGSEiGP UAM, Seria Rozwój Regionalny i Polityka Regionalna, 8, Bogucki Wydawnictwo Naukowe, Poznań: 7-20.

Malaga K. \& Kliber P., 2007. Konwergencja i nierówności regionalne $w$ Polsce $w$ świetle neoklasycznych modeli wzrostu (Convergence and regional disparities in Poland in the light of neoclassical growth models). Wydawnictwo Akademii Ekonomicznej w Poznaniu, Poznań.

Maurseth P.B., 2001. Convergence, geography and technology. Structural change and economic dynamics 12: 247-276.

Mотек P., 2006. Gospodarka finansowa samorzadu terytorialnego w województwie wielkopolskim (The finance of the local government of Wielkopolska voivodeship). Bogucki Wydawnictwo Naukowe, Poznań.

Petrakos G., 2001, Patterns of regional inequality in transition economics. European Planning Studies 9 (3): 359-383.

RATAJCZAK W., 2008a. Modele ekonometrii przestrzennej w analizie regionalnej (Spatial econometric models in regional analysis). In: Stryjakiewicz T. \& Czyż T. (eds), O nowy $k s z t a t t$ badań regionalnych $w$ geografii $i$ gospodarce przestrzennej. Biuletyn KPZK PAN 237: 323-344.

RATAJCZAK W., 2008b. Innowacyjność a konkurencyjność polskich regionów (Innovativeness and competitiveness of the Polish regions). In: Parysek J.J. \& Stryjakiewicz T. (eds), Region społeczno-ekonomiczny i rozwój regionalny. Bogucki Wydawnictwo Naukowe, Poznań: 299-313.

Rodriguez-Lopez J., Martinez-Lopez D. \& Romero-Avila D., 2009. Persistence of inequalities across the Spanish regions. Papers in Regional Science 88 (4): 841-862.

Sме̨ткоWSKi M. \& Wójcik P., 2009. Rozwój regionalny w Europie Środkowo-Wschodniej (Regional development in Central and Eastern Europe). Studia Regionalne i Lokalne 4 (38): 39-66.

Wóscik P., 2008. Dywergencja czy konwergencja: Dynamika rozwoju polskich regionów (Divergence or convergence: Development dynamics of the Polish regions). Studia Regionalne i Lokalne 2 (32): 41-71. 